\title{
SarkoSpin: A Technique for Biochemical Isolation and Characterization of Pathological TDP-43 Aggregates
}

Manuela Pérez-Berlanga, Florent Laferrière ${ }^{\$}$ and Magdalini Polymenidou*

\author{
Department of Quantitative Biomedicine, University of Zurich, Switzerland; ${ }^{\$}$ Current address: Institut des \\ Maladies Neurodégénératives, Université de Bordeaux, France \\ *For correspondence: magdalini.polymenidou@uzh.ch
}

\begin{abstract}
[Abstract] TDP-43 is the main aggregating protein in neurodegenerative diseases such as amyotrophic lateral sclerosis (ALS) and frontotemporal lobar degeneration (FTLD). Aggregated TDP-43 is resistant to diverse detergent solubilization, yet physiological TDP-43 and other abundant proteins commonly copurify with pathological TDP-43. This mixed isolation has precluded the elucidation of the biochemical and structural features of the pathological TDP-43 and its role in disease. Here we describe SarkoSpin, a method for the isolation of pure pathological TDP-43 from patient autopsy brain by sample solubilization with Sarkosyl after nuclease treatment. This purification, which is also applicable to cell culture material, permits the study of biochemical properties of exclusively pathological TDP-43, allowing for the first time the determination of their link to the clinical presentation of FTLD. This method opens up a path for the study of pathological TDP-43 at the molecular and structural level in the heterogeneous spectrum of ALS and FTLD cases.
\end{abstract}

Keywords: TDP-43, Aggregation, SarkoSpin, ALS, FTLD

[Background] Protein aggregation in affected neurons is a hallmark of neurodegenerative diseases (Soto et al., 2003). In two of the most devastating forms, amyotrophic lateral sclerosis (ALS) and frontotemporal lobar degeneration (FTLD), the principal aggregating protein is TAR-DNA binding protein 43 (TDP-43) (Ling et al., 2013). Under pathological conditions, TDP-43 is abnormally ubiquitinated, hyperphosphorylated and proteolytically cleaved, and is sequestered in insoluble cytoplasmic inclusions that include both the full-length protein as well as its highly-aggregation prone C-terminal fragment (Neumann et al., 2006; Arai et al., 2006). TDP-43 inclusions account for virtually all ALS patients and for up to $45 \%$ of FTLD patients, suggesting that ALS and FTLD are the two ends of a single clinical, genetic and pathological spectrum (Ling et al., 2013). FTLD cases can be subdivided into at least three subtypes (A, B and C) based on the shape and location of the aggregated TDP-43 (Lee et al., 2017), and it was recently shown that different biochemical features of the pathological TDP-43 may underlie this heterogeneity (Laferriere et al., 2019).

An RNA-binding protein (Buratti et al., 2001), TDP-43 forms physiological oligomers that are required to perform its indispensable role in RNA splicing regulation (Afroz et al., 2017). Pathological TDP-43 becomes resistant to solubilization by a wide range of detergents, but its isolation from physiological TDP-43 in brain tissue is hindered by protein-protein and protein-RNA interactions in the lysate. TDP- 
43 and other RNA-binding proteins containing low complexity domains may form homo- and heterooligomeric species in complex with nucleic acids that become partially insoluble.

Here, we describe SarkoSpin, a purification assay for the isolation of pathological TDP-43 from patient brain tissue by utilizing a single-step solubilization with nuclease treatment (Laferriere et al., 2019). This technique allows for the isolation of pure pathological TDP-43 from $99.8 \%$ of the total protein mass, including proteins that form big complexes in their physiological state, such as actin or histones. Isolated TDP-43 is pathologically modified and becomes polyubiquitination, hyperphosphorylated and Cterminally cleaved. Importantly, purified TDP-43 is free from the presence of other RNA-binding proteins containing low-complexity domains, such as hnRNPA1 (heterogeneous nuclear ribonucleoprotein $\underline{A} 1$ ),

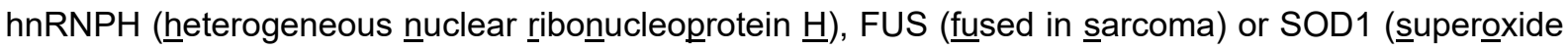
dismutase 1), which are also associated with ALS and FTLD. The isolation of pure fractions of pathological TDP-43 in combination with other high-resolution techniques will represent a major advancement in the understanding of the molecular mechanisms and structural differences of TDP-43 underlying ALS and FTLD heterogeneity.

\section{Materials and Reagents}

1. Open-top tubes for an SW60 rotor. e.g., Open-top polyclear tubes 7/16x2-3/8" (Seton, catalog number: 7010)

2. Filtered pipet tips (any commercially available are suitable, examples in brackets)
a. $\quad 10 \mu$ filter tip (STARLAB, catalog number: S1121-3810)
b. $20 \mu$ filter tip (STARLAB, catalog number: S1120-1810)
c. $200 \mu$ filter tip (STARLAB, catalog number: S1120-8810)
d. $1000 \mu$ filter tip (STARLAB, catalog number: S1122-1830)

3. $15 \mathrm{ml}$ tubes (any commercially available are suitable, e.g., Greiner Bio-One, catalog number: 188271)

4. $50 \mathrm{ml}$ tubes (any commercially available are suitable, e.g., Greiner Bio-One, catalog number: 227261)

5. 6-well tissue culture plates (any commercially available are suitable, e.g., TPP catalog number: 92006)

6. Protein LoBind tubes $1.5 \mathrm{ml}$ (Eppendorf, catalog number: 0030108116)

7. Divisible $250 \mu$ l 96-well PCR plates (Eppendorf, catalog number: 0030133374)

8. N-Lauroylsarcosine sodium salt (Sarkosyl, Sigma, catalog number: L5125-100G)

9. Trizma $^{\circledR}$ hydrochloride (Tris- $\mathrm{HCl}$, Sigma, catalog number: T3253-1KG)

10. Sodium chloride ( $\mathrm{NaCl}$, Sigma, catalog number: 71380$)$

11. EDTA disodium salt dihydrate (Amresco, catalog number: 0105-1KG)

12. DL-Dithiothreitol (DTT, Thermo Scientific, catalog number: R0861)

13. Phosphatase inhibitors. e.g., PhosSTOP (Roche, catalog number: 4906837001)

14. Complete Mini EDTA-free Protease Inhibitor Cocktail (Roche, catalog number: 11836170001) 
15. Lysing kit for tissue homogenizing CKMix (Precellys, catalog number: P000918-LYSK0-A)

16. Magnesium chloride ( $\mathrm{MgCl}_{2}$, Sigma-Aldrich, catalog number: $\left.\mathrm{M} 8266-100 \mathrm{G}\right)$

17. Benzonase nuclease HC, purity $>90 \% 25 \mathrm{KU}$ (Merck, catalog number: $71205-3$ )

18. Cell culture grade phosphate buffered saline (PBS Gibco, catalog number: 10010015)

19. Sucrose (Millipore, catalog number: 84100 )

20. OptiPrep ${ }^{\mathrm{TM}}$ Density Gradient Medium (Sigma-Aldrich, catalog number: D1556)

21. Dry ice

22. Distilled water (Invitrogen, catalog number: 10977035)

23. 2x Homogenization-solubilization (HS) buffer (see Recipes)

24. $1 x$ HS buffer (see Recipes)

25. Benzonase mix (see Recipes)

26. $2 x$ HS buffer $4 \%$ Sarkosyl (w/v) (see Recipes)

27. $1 \times$ HS buffer $0.5 \%$ Sarkosyl (w/v) (see Recipes)

28. Benzonase mix for cell (see Recipes)

29. Sucrose cushion (see Recipes)

30. $8 x$ HS buffer $4 \%$ Sarkosyl (w/v) (see Recipes)

31. $2 x$ HS buffer $1 \%$ Sarkosyl (w/v) (see Recipes)

\section{Equipment}

1. Forceps (any commercially available are suitable, e.g., VWR, catalog number 232-1221)

2. Scalpel (any commercially available is suitable, e.g., VWR, catalog number 233-5363)

3. $-80^{\circ} \mathrm{C}$ freezer for storage of homogenate aliquots (any commercially available freezer is suitable)

4. Minilys homogenizer (P000673-MLYSO-A, Bertin technologies)

5. Bucket for dry ice (any commercially available is suitable, e.g., Fisher Scientific, catalog number, 11324085)

6. Thermo Mixer C (Eppendorf, catalog number: 5382000015) with SmartBlock $1.5 \mathrm{ml}$ (Eppendorf, catalog number: 5360000038)

7. Bench top centrifuge. e.g., Prism ${ }^{\mathrm{TM}}$ Microcentrifuge (Labnet International, C2500)

8. Gradient Master Base Unit (BioComp, \#108) with 7/16" $(11 \mathrm{~mm})$ Magnabase $^{\mathrm{TM}}$ holder and marker block for SW60 rotor short caps (BioComp, \#105-911A-R)

9. Ultracentrifuge. e.g., OPTIMATM XPN-100 ultracentrifuge (Beckman Coulter, A99846)

10. SW 60 Ti Swinging-Bucket Rotor (Beckman Coulter, 335649)

11. Vortex (any commercially available freezer is suitable; e.g., Scientific Industries, SI-0236)

12. Micropipettes (any commercially available are suitable, examples in brackets)

P10 (Eppendorf, catalog number: 3120000020)

P20 (Eppendorf, catalog number: 3120000038)

P200 (Eppendorf, catalog number: 3120000054)

P1000 (Eppendorf, catalog number: 3120000062) 
13. Piston gradient fractionator (BioComp, 152)

14. Fraction collector (Gilson, FC203B)

\section{Procedure}

A. Homogenization of tissue (Figure 1A)

\section{A. HOMOGENIZATION}

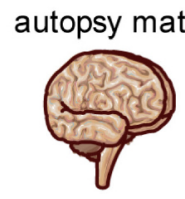

HS buffer
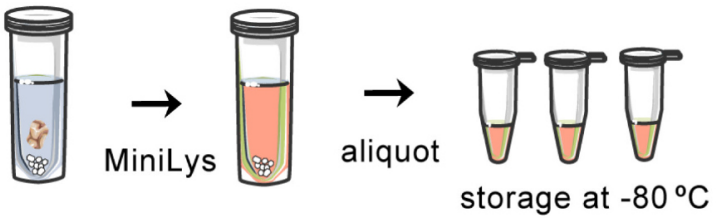

B. SOLUBILIZATION

C. ISOLATION
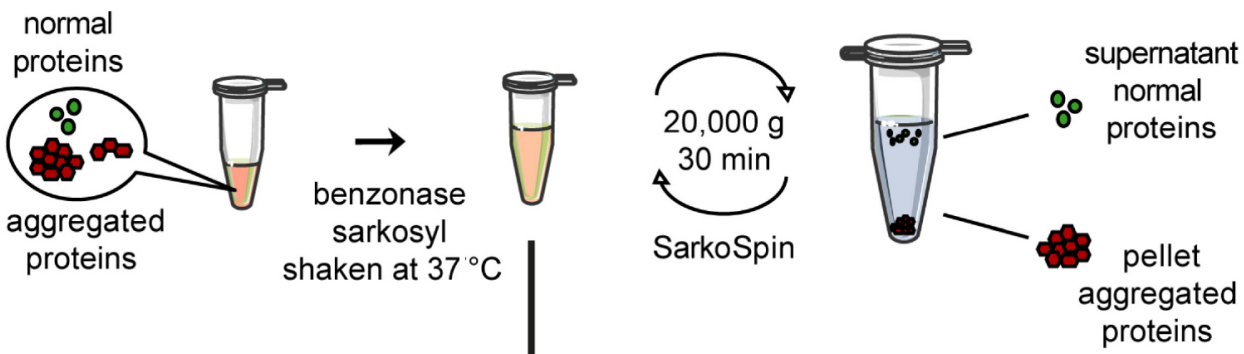

D. VELOCITY SEDIMENTATION

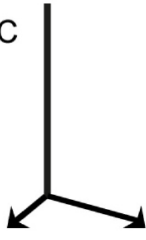

\section{E. DENSITY FLOTATION}

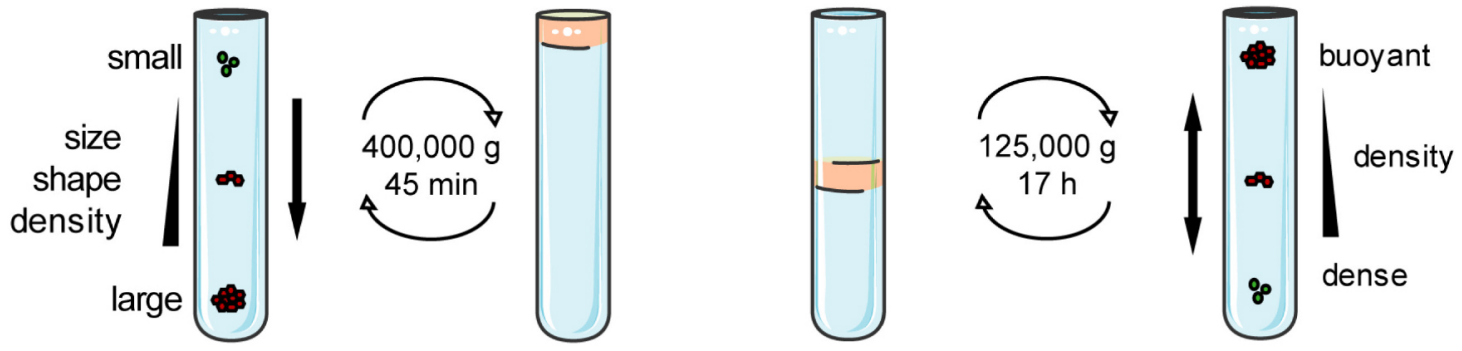

Figure 1. Schematic representation of the SarkoSpin protocol. A. Brain autopsy tissue is mechanically homogenized and divided into single-use aliquots, which are snap-frozen for future uses. B. Aliquoted homogenates are solubilized in a sarkosyl-based buffer and treated with nuclease in order to disrupt major protein-protein and protein-RNA complexes, before C. the bulk of insoluble pathological TDP-43 can be isolated in a single spin. (D, E) Alternatively, the biochemical properties of the insoluble pathological TDP-43 can be analyzed by different analytical centrifugation methods. 
1. Take the patient samples out of the $-80^{\circ} \mathrm{C}$ freezer into a box containing dry ice to avoid thawing of the tissue while processing.

2. Place the brain sample on the balance over a paper and let it thaw slightly.

3. Cut a piece with a maximum weight of $300 \mathrm{mg}$ from the brain sample with a sterile scalpel and autoclaved forceps.

4. Return the remainder of the sample into dry ice to avoid further thawing and damage of the tissue.

5. Chop the brain sample on the balance into smaller portions with the sterile scalpel.

6. For homogenization, transfer the tissue pieces into the $2 \mathrm{ml}$-tube from the lysing kit, containing a mixture of ceramic beads with a diameter of 1.4 and $2.8 \mathrm{~mm}$.

7. Add HS buffer in a ratio of $5: 1$ to the amount of tissue. For example, for the maximum of 300 mg per tube, add $1.5 \mathrm{ml}$ 1x HS buffer (Recipe 2).

8. Homogenize the samples in a Minilys device three times for $30 \mathrm{~s}$ each at maximum speed. Cool down the sample on ice between rounds.

9. Let the sample set down for the froth to disappear. A short spin of the tube in a table-top microfuge will help.

10. Vortex quickly at low speed while avoiding creating new froth.

11. Divide the homogenate into aliquots of $150 \mu \mathrm{l}$ in low protein binding $1.5 \mathrm{ml}$ tubes.

12. Keep $10 \mu \mathrm{l}$ aliquot from the original homogenate to check levels of phosphorylated TDP-43 in the sample by Western blot and $5 \mu \mathrm{l}$ for protein concentration determination (directly add to 45 $\mu \mathrm{l} 1 \mathrm{x}$ HS buffer to dilute it). This step will allow determining whether homogenates indeed have comparable starting protein concentrations, and therefore SarkoSpin the on homogenates from different brain samples will be comparable.

13. Snap-freeze the $150 \mu \mathrm{l}$ aliquots on dry ice and store at $-80^{\circ} \mathrm{C}$. Homogenate aliquots are good for SarkoSpin purification for months to years if properly stored at $-80^{\circ} \mathrm{C}$.

B. Solubilization (Figure 1B)

1. Thaw the homogenate aliquots (from Step A13) on ice.

2. Add $50 \mu$ l of Benzonase mix (Recipe 3 ) to each sample.

3. Incubate at room temperature for $5 \mathrm{~min}$.

4. Add $200 \mu \mathrm{l}$ of $2 x \mathrm{HS}$ buffer $4 \%$ Sarkosyl (Recipe 4 ) to each sample.

5. Incubate in a Thermo Mixer at $38{ }^{\circ} \mathrm{C}$ and shaking at $600 \mathrm{rpm}$ for $45 \mathrm{~min}$.

When performing SarkoSpin from cultured cell samples, cell lysis and solubilization are performed in a combined step as follows:

1. Per well of a 6 -well plate, lyse cells in $100 \mu \mathrm{l} 1 \mathrm{x}$ HS buffer $0.5 \%$ Sarkosyl.

2. Add $5 \mu$ l of Benzonase mix for cells (Recipe 3 ).

3. Incubate for $5 \mathrm{~min}$ at RT.

4. Scrape the cells and transfer the lysate to a low protein binding $1.5 \mathrm{ml}$ tube. 
5. Wash the well with additional $100 \mu \mathrm{l}$ of $1 \mathrm{x}$ HS buffer $0.5 \%$ Sarkosyl and transfer to the tube.

6. Vortex to homogenize.

7. Transfer $170 \mu \mathrm{l}$ of the lysate into a new low protein binding $1.5 \mathrm{ml}$ tube, leaving $5 \mu \mathrm{l}$ for protein concentration determination and $30 \mu \mathrm{l}$ for Western blot analysis of total lysate.

8. Add $178 \mu \mathrm{l} 2 \mathrm{x}$ HS $4 \%$ Sarkosyl and $1 \mathrm{x}$ HS to $170 \mu \mathrm{l}$ of lysate, for a final concentration of $2 \%$ Sarkosyl in a volume of $400 \mu \mathrm{l}$ (like for brain homogenates solubilization).

9. Incubate on ice for $45 \mathrm{~min}$, vortexing in intervals of $10 \mathrm{~min}$.

10. Proceed with the rest of the protocol as for the brain homogenates.

C. Isolation (Figure 1C)

1. Add $200 \mu \mathrm{l}$ of ice-cold $1 \times$ HS buffer $0.5 \%$ Sarkosyl (Recipe 5 ) to each sample.

2. Centrifuge at $21,200 \times g$ for $30 \mathrm{~min}$ at room temperature (RT) in a bench top centrifuge.

3. Label low protein binding $1.5 \mathrm{ml}$ tubes with the sample name and "Supernatant/"Pellet".

4. After the centrifugation, remove up to $500 \mu \mathrm{l}$ of the supernatant and keep it aside in the tube pre-labeled as "Supernatant".

5. Carefully remove the remaining supernatant with a gel-loading tip and discard.

6. Let the sample stand for one minute and repeat Step C5 to ensure that all supernatant is removed.

7. Carefully wash the pellet (brown) and tube walls with $100 \mu \mathrm{l}$ cell culture grade PBS. Lipids can appear as a white layer above the protein pellet and can be carefully washed away with the PBS (for complete removal of lipids in the sample, see below).

8. Remove all traces of PBS by repeating Steps C5 and C6.

9. Resuspend the pellet in the desired amount of $1 \times$ HS buffer $0.5 \%$ Sarkosyl and transfer to the tube pre-labeled as "Pellet".

If samples are not going to be immediately used for analysis, do not resuspend in the pellet. Snap-freeze the samples on dry ice and store at $-80^{\circ} \mathrm{C}$.

10. Proceed to pellet analysis by SDS-PAGE, native PAGE or dot blot and Western blot (Data analysis, Figure 2). 


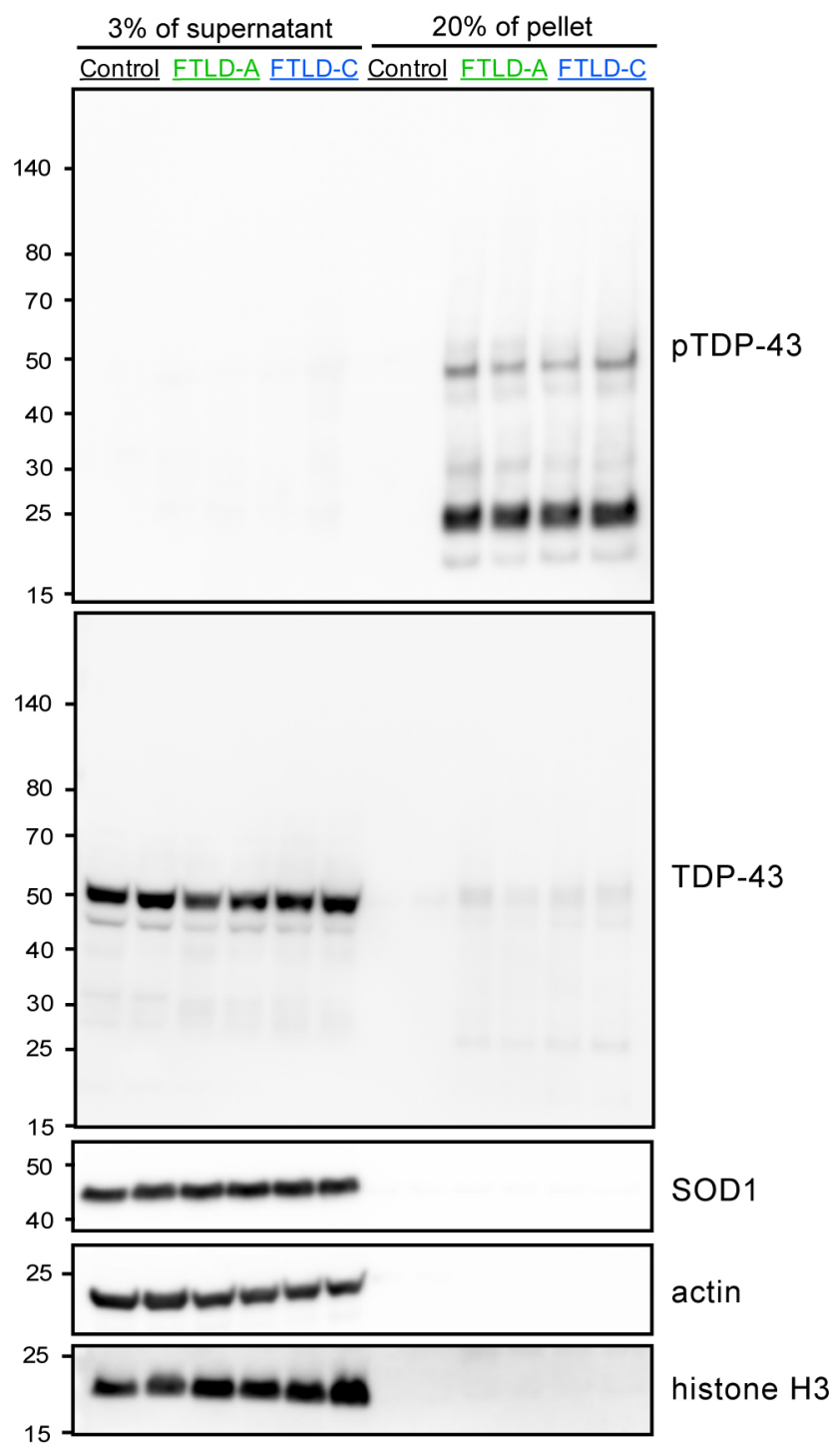

Figure 2. Representative Western blots of the supernatant and pellet fractions from SarkoSpin isolation. Pathological phosphorylated TDP-43 is enriched in the pellet fraction of samples from FTLD patients but not in healthy controls, while the bulk of the physiological TDP43 remains soluble. Importantly, abundant cellular proteins such as SOD1, actin and histone H3 also remain in the supernatant fraction.

In order to avoid co-precipitation of lipids and proteins, SarkoSpin can alternatively be performed over a cushion of sucrose as follows (continues from Step B5):

a. Lay $400 \mu \mathrm{l}$ of solubilized homogenates over $400 \mu \mathrm{l}$ of sucrose cushion (Recipe 7 ) in low protein binding $1.5 \mathrm{ml}$ tubes.

b. Centrifuge at $21,200 \times g$ for $30 \mathrm{~min}$ at room temperature (RT) in a bench top centrifuge.

c. Proceed with the protocol as described from Step C3 on.

D. Velocity sedimentation assay (Figure 1D, continues from Step B5) 
1. Prepare the OptiPrep gradient cushions as indicated in Table 1.

Table 1. Recipe for the OptiPrep gradient cushions required for the velocity sedimentation assay. For $2 x$ HS buffer $1 \%$ Sarkosyl, see Recipe 9. For the commercial OptiPrep solution (60\%), see Materials and Reagents.

\begin{tabular}{lcc}
\hline Reagents & $10 \%$ OptiPrep & $25 \%$ OptiPrep \\
\hline 2x HS buffer 1\% Sarkosyl & $9 \mathrm{ml}$ & $9 \mathrm{ml}$ \\
OptiPrep solution (60\%) & $3 \mathrm{ml}$ & $7.5 \mathrm{ml}$ \\
Distilled water & $6 \mathrm{ml}$ & $1.5 \mathrm{ml}$ \\
Total volume & $18 \mathrm{ml}$ & $18 \mathrm{ml}$ \\
\hline
\end{tabular}

2. Use a Gradient Master to prepare the linear OptiPrep gradient in $4.2 \mathrm{ml} \mathrm{SW60} \mathrm{rotor} \mathrm{tubes} \mathrm{as}$ follows:

a. With the tube in the marker block for an SW 60 Ti rotor, draw a line at the middle of the tube for short caps.

b. Pipette the $10 \%$ OptiPrep cushion into the tube until a few $\mathrm{mm}$ above the drawn line.

c. Carefully inject the $25 \%$ OptiPrep cushion at the bottom of the tube with the provided steel cannula, thereby pushing the previous $10 \%$ OptiPrep cushion up, until the interface reaches the mid-tube mark.

d. Close the tube with the provided short cap, removing the remaining air inside.

e. Use the scroll and spirit level on the Gradient Master in order to make the Magnabase horizontal.

f. Place the tubes in the Magnabase, and transfer onto the Gradient Master plate.

g. Run the program: SW60-1 step://1 $\min 10 \mathrm{~s} / / 82^{\circ} / / 20 \mathrm{rpm} / /$.

h. Once finished, carefully remove the tube caps and remove approximately $150 \mu \mathrm{l}$ of the upper layer of the gradient.

i. Weigh the tubes containing the gradients and balance them as precisely as possible (to the decigram level).

3. Carefully lay $200 \mu \mathrm{l}$ of the solubilized homogenate (Step B5) over the top of the gradient.

4. Ultracentrifuge at $400,000 \times g$ for 45 min at $4{ }^{\circ} \mathrm{C}$ with maximum acceleration and deceleration.

5. Carefully remove the tubes from the centrifuge buckets with tweezers and keep them at $4{ }^{\circ} \mathrm{C}$ before fractionation with a piston fractionator associated with a fraction collector.

6. Insert a divisible $250 \mu \mathrm{l} \mathrm{PCR}$ in the collector holder.

7. Rinse the piston before and after each gradient by fractionating of a tube filled with water and using the "rinse" button.

8. Air dry the piston after the washing steps by opening the air screw and pressing the button Air to make it blow through the piston. Screw it back gently after drying.

9. Place the gradient to fractionate in the tube holder, clipped with the cap.

10. Let the piston go down with the position roll until the liquid reaches the collector head. 
11. Reset position and enter the program the following program: Speed: $0.5 /$ Distance: $2.96 /$ Number: 16

12. Press Start. The fractionator will automatically fractionate the gradient into 16 fractions in the divisible 96-well PCR plate.

13. Repeat the washing and drying (Steps D7 and D8) before fractionating another gradient.

E. Density flotation assay (Figure 1E, continues from Step B5)

1. Prepare the OptiPrep gradient cushions as indicated in Table 2.

Table 2. Recipe for the OptiPrep gradient cushions required for the density flotation assay. For $8 x$ HS buffer $4 \%$ Sarkosyl, see Recipe 8 . For the OptiPrep solution (60\%), see Materials and Reagents.

\begin{tabular}{lcccc}
\hline Regents & $\begin{array}{c}10 \% \\
\text { OptiPrep }\end{array}$ & $\begin{array}{c}20 \% \\
\text { OptiPrep }\end{array}$ & $\begin{array}{c}30 \% \\
\text { OptiPrep }\end{array}$ & $\begin{array}{c}50 \% \\
\text { OptiPrep }\end{array}$ \\
\hline 8x HS buffer 4\% Sarkosyl & $750 \mu \mathrm{l}$ & $750 \mu \mathrm{l}$ & $750 \mu \mathrm{l}$ & $1125 \mu \mathrm{l}$ \\
OptiPrep solution $(60 \%)$ & $1000 \mu \mathrm{l}$ & $2000 \mu \mathrm{l}$ & $3000 \mu \mathrm{l}$ & $7500 \mu \mathrm{l}$ \\
Distilled water & $4250 \mu \mathrm{l}$ & $3250 \mu \mathrm{l}$ & $2250 \mu \mathrm{l}$ & $375 \mu \mathrm{l}$ \\
Total volume & $6000 \mu \mathrm{l}$ & $6000 \mu \mathrm{l}$ & $6000 \mu \mathrm{l}$ & $9000 \mu \mathrm{l}$ \\
\hline
\end{tabular}

2. In order to prepare the discontinuous OptiPrep gradient, carefully lay the OptiPrep cushions in $4.2 \mathrm{ml} \mathrm{SW60}$ rotor tubes to create the discontinuous gradient in the following order (highest concentration at the bottom):

$300 \mu \mathrm{l}$ of pure $(60 \%)$ OptiPrep solution

$700 \mu \mathrm{l}$ of the $50 \%$ OptiPrep cushion

$800 \mu \mathrm{l}$ of the mix ( $220 \mu \mathrm{l}$ of solubilized homogenate from step B5 $+680 \mu \mathrm{l} 50 \%$ OptiPrep cushion) for a final OptiPrep concentration of $40 \%$

$800 \mu \mathrm{l}$ of the $30 \%$ OptiPrep cushion

$800 \mu \mathrm{l}$ of the $20 \%$ OptiPrep cushion

$800 \mu \mathrm{l}$ of the $10 \%$ OptiPrep cushion

Weigh the tubes after pipetting each cushion to balance them to the decigram level.

3. Ultracentrifuge at $125,000 \times g$ for $17 \mathrm{~h}$ at $4{ }^{\circ} \mathrm{C}$ with maximum acceleration and deceleration.

4. Fractionate as describe from Step D5.

\section{Data analysis}

Depending on the application of the SarkoSpin isolation, insoluble TDP-43 can be analyzed with a wide variety of techniques, ranging from Western blots (after SDS-PAGE, native PAGE or filter retardation assay, Figure 2) to high-resolution techniques like electron microscopy or mass spectrometry (Laferriere et al., 2019). 


\section{Recipes}

1. $2 x$ Homogenization-solubilization (HS) buffer

$20 \mathrm{mM}$ Tris, $\mathrm{pH} 7.5$

$300 \mathrm{mM} \mathrm{NaCl}$

1 mM EDTA

$2 \mathrm{mM}$ DTT, with protease and phosphatase inhibitors

Stable at $4{ }^{\circ} \mathrm{C}$ for one month without inhibitors

\section{For $50 \mathrm{ml}$ :}

$1 \mathrm{ml}$ of $1 \mathrm{M}$ Tris- $\mathrm{HCl}$, pH 7.4 (78.8 g Tris- $\mathrm{HCl}$ in $500 \mathrm{ml} \mathrm{H} \mathrm{H}_{2}$, filtered-sterilized and stored at RT)

$6 \mathrm{ml}$ of $2.5 \mathrm{M} \mathrm{NaCl}$ (36.53 g NaCl in $250 \mathrm{ml} \mathrm{H}_{2} \mathrm{O}$, filtered-sterilized and stored at RT)

$100 \mu \mathrm{l}$ of $0.5 \mathrm{M}$ EDTA, pH 8 (93.06 g EDTA disodium salt dihydrate in $500 \mathrm{ml} \mathrm{H} \mathrm{H}_{2} \mathrm{O}$, pH adjusted to 8 , filtered-sterilized and stored at RT)

$100 \mu \mathrm{l}$ of $1 \mathrm{M}$ DTT ( $1.5 \mathrm{~g}$ of DTT in $8 \mathrm{ml}$ of $\mathrm{H}_{2} \mathrm{O}$, aliquoted in single-use amounts and stored at $\left.20{ }^{\circ} \mathrm{C}\right)$

Fill up with distilled water to $50 \mathrm{ml}$ (approx. $42.8 \mathrm{ml}$ )

For every $10 \mathrm{ml}$ of $2 x$ HS buffer, 2 tablets Complete Mini EDTA-free and 1 tablet PhosSTOP

2. $1 \mathrm{x}$ HS buffer

$10 \mathrm{mM}$ Tris, $\mathrm{pH} 7.4,15 \mathrm{mM} \mathrm{NaCl}, 0.5 \mathrm{mM}$ EDTA, $1 \mathrm{mM}$ DTT, with protease and phosphatase inhibitors

\section{For $10 \mathrm{ml}$ :}

$5 \mathrm{ml} 2 \mathrm{x}$ HS buffer

$5 \mathrm{ml}$ distilled water

3. Benzonase mix

$12 \mathrm{mM} \mathrm{MgCl}_{2} 1 \times \mathrm{HS}$ buffer with $250 \mathrm{U} /$ sample Benzonase

\section{For $50 \mu \mathrm{l}$ :}

$1 \mu$ l Benzonase $\mathrm{HC}$

$50 \mu \mathrm{l} 1 \mathrm{x}$ HS buffer

$1.4 \mu \mathrm{l} 500 \mathrm{mM} \mathrm{MgCl}_{2}\left(2.38 \mathrm{~g} \mathrm{MgCl}_{2}\right.$ in $50 \mathrm{ml} \mathrm{H}_{2} \mathrm{O}$, filtered-sterilized and stored at $4{ }^{\circ} \mathrm{C}$ )

4. $2 x$ HS buffer $4 \%$ Sarkosyl (w/v)

$400 \mathrm{mg}$ Sarkosyl per $10 \mathrm{ml}$ of $2 x \mathrm{HS}$ buffer

5. $1 \times$ HS buffer $0.5 \%$ Sarkosyl $(w / v)$

$50 \mathrm{mg}$ Sarkosyl per $10 \mathrm{ml}$ of $1 \mathrm{x}$ HS buffer

6. Benzonase mix for cells

$60 \mathrm{mM} \mathrm{MgCl} 21 \times$ HS buffer with $100 \mathrm{U} /$ well Benzonase

\section{For $6 \mu \mathrm{l}$ :}

$0.4 \mu$ l Benzonase $\mathrm{HC}$

$5 \mu \mathrm{l} 1 \mathrm{x}$ HS buffer

$0.6 \mu \mathrm{l} 500 \mathrm{mM} \mathrm{MgCl} 2$ 
7. Sucrose cushion

$40 \%$ sucrose $(w / v)$ in $1 x$ HS buffer

For $400 \mu \mathrm{\mu l}$ :

$160 \mathrm{mg}$ sucrose

Fill up to $400 \mu \mathrm{l}$ with $1 \mathrm{X}$ HS buffer

8. $8 x$ HS buffer $4 \%$ Sarkosyl (w/v)

$80 \mathrm{mM}$ Tris, $\mathrm{pH}$ 7.5, $1.2 \mathrm{M} \mathrm{NaCl}, 4 \mathrm{mM}$ EDTA, $8 \mathrm{mM}$ DTT, with protease inhibitors and $4 \%$ Sarkosyl (w/v). Stable at $4{ }^{\circ} \mathrm{C}$ for one month without inhibitors (f)

For $4 \mathrm{ml}$ :

$320 \mu \mathrm{l}$ of $1 \mathrm{M}$ Tris- $\mathrm{HCl} \mathrm{pH} 7.4$

$960 \mu$ of $2.5 \mathrm{M} \mathrm{NaCl}$

$32 \mu \mathrm{l}$ of $0.5 \mathrm{M}$ EDTA pH 8

$32 \mu \mathrm{l}$ of $1 \mathrm{M}$ DTT

Fill up with distilled water to $4 \mathrm{ml}$ (approx. $2656 \mu \mathrm{l}$ )

1 tablet cOmplete Mini EDTA-free

$160 \mathrm{mg}$ Sarkosyl

9. $2 x$ HS buffer $1 \%$ Sarkosyl (w/v)

$100 \mathrm{mg}$ Sarkosyl per $10 \mathrm{ml}$ of $2 x \mathrm{HS}$ buffer

\section{Acknowledgments}

M. P. is the recipient of a Swiss National Science Foundation Professorship (PP00P3_144862), a Human Frontier Science Program Career Development Award (CDA-00058/2012) and a UCL/ZNZ Neuroscience Collaboration Grant funded through UCL's Welcome Trust Institutional Strategic Support Fund Investing in Excellent Researchers (105604/Z/14/Z). M.P.-B. received a Candoc Award (Forschungskredit) from the University of Zurich. F.L. is supported by the Milton-Safenowitz fellowship from the ALS Association (15-IIP-208) and a Postdoc Award from the University of Zurich. This protocol is based on the publication Laferriere et al., 2019.

\section{Competing interests}

The authors declare no competing financial interests.

\section{Ethics}

The Queen Square Brain Bank for Neurological disorders (UCL Institute of Neurology), the Department of Neurology (University of California San Diego) or the Netherlands Brain Bank (Netherlands Institute for Neuroscience) provided the brain autopsy material. Brain tissue was 
Please cite this article as: Pérez-Berlanga et. al., (2019). SarkoSpin: A Technique for Biochemical Isolation and Characterization of Pathological TDP-43

donated upon written informed consent from all subjects and the respective institution obtained the clinical information for research purposes.

\section{$\underline{\text { References }}$}

1. Afroz, T., Hock, E. M., Ernst, P., Foglieni, C., Jambeau, M., Gilhespy, L. A. B., Laferriere, F., Maniecka, Z., Pluckthun, A., Mittl, P., Paganetti, P., Allain, F. H. T. and Polymenidou, M. (2017). Functional and dynamic polymerization of the ALS-linked protein TDP-43 antagonizes its pathologic aggregation. Nat Commun 8(1): 45.

2. Arai, T., Hasegawa, M., Akiyama, H., Ikeda, K., Nonaka, T., Mori, H., Mann, D., Tsuchiya, K., Yoshida, M., Hashizume, Y. and Oda, T. (2006). TDP-43 is a component of ubiquitin-positive tau-negative inclusions in frontotemporal lobar degeneration and amyotrophic lateral sclerosis. Biochem Biophys Res Commun 351(3): 602-611.

3. Buratti, E., Dork, T., Zuccato, E., Pagani, F., Romano, M. and Baralle, F. E. (2001). Nuclear factor TDP-43 and SR proteins promote in vitro and in vivo CFTR exon 9 skipping. EMBO J 20(7): 1774-1784.

4. Laferriere, F., Maniecka, Z., Perez-Berlanga, M., Hruska-Plochan, M., Gilhespy, L., Hock, E. M., Wagner, U., Afroz, T., Boersema, P. J., Barmettler, G., Foti, S. C., Asi, Y. T., Isaacs, A. M., AlAmoudi, A., Lewis, A., Stahlberg, H., Ravits, J., De Giorgi, F., Ichas, F., Bezard, E., Picotti, P., Lashley, T. and Polymenidou, M. (2019). TDP-43 extracted from frontotemporal lobar degeneration subject brains displays distinct aggregate assemblies and neurotoxic effects reflecting disease progression rates. Nat Neurosci 22(1): 65-77.

5. Lee, E. B., Porta, S., Michael Baer, G., Xu, Y., Suh, E., Kwong, L. K., Elman, L., Grossman, M., Lee, V. M., Irwin, D. J., Van Deerlin, V. M. and Trojanowski, J. Q. (2017). Expansion of the classification of FTLD-TDP: distinct pathology associated with rapidly progressive frontotemporal degeneration. Acta Neuropathol 134(1): 65-78.

6. Ling, S. C., Polymenidou, M. and Cleveland, D. W. (2013). Converging mechanisms in ALS and FTD: disrupted RNA and protein homeostasis. Neuron 79(3): 416-438.

7. Neumann, M., Sampathu, D. M., Kwong, L. K., Truax, A. C., Micsenyi, M. C., Chou, T. T., Bruce, J., Schuck, T., Grossman, M., Clark, C. M., McCluskey, L. F., Miller, B. L., Masliah, E., Mackenzie, I. R., Feldman, H., Feiden, W., Kretzschmar, H. A., Trojanowski, J. Q. and Lee, V. M. (2006). Ubiquitinated TDP-43 in frontotemporal lobar degeneration and amyotrophic lateral sclerosis. Science 314(5796): 130-133.

8. Soto, C. (2003). Unfolding the role of protein misfolding in neurodegenerative diseases. Nat Rev Neurosci 4(1): 49-60. 